OPEN ACCESS

Edited by:

Gael Le Roux,

EcoLab Toulouse (CNRS), France

Reviewed by:

Victor Frossard

University of Savoy, France

*Correspondence:

Isabelle Larocque-Tobler

isabella.larocque@

thelakesinstitute.com

Specialty section: This article was submitted to

Paleoecology,

a section of the journal

Frontiers in Ecology and Evolution

Received: 20 July 2016 Accepted: 11 August 2016 Published: 14 October 2016

Citation:

Larocque-Tobler I (2016) Editorial: Using Paleolimnology for Lake

Restoration and Management.

Front. Ecol. Evol. 4:103.

doi: 10.3389/fevo.2016.00103

\section{Editorial: Using Paleolimnology for Lake Restoration and Management}

\author{
Isabelle Larocque-Tobler* \\ The L.A.K.E.S. Institute, Lyss, Switzerland
}

Keywords: paleolimnology, lake sediments, lake restoration, wetlands, lake management

\section{The Editorial on the Research Topic}

\section{Using Paleolimnology for Lake Restoration and Management}

Paleolimnology has been used for decades to reconstruct past environments and more recently, to quantify the observed changes. Various organisms preserve in sediment of lakes and wetlands and can be used to reconstruct how a water body and the surrounding landscape looked like and has changed through time. For example, pollen, charcoal, and macrofossils can be used to reconstruct vegetation and frequency of fires at the local and regional scale, diatoms, and Cladocera can be used to reconstruct changes in $\mathrm{PH}$ and nutrients and insects are indicators of lake level, oxygen concentration, nutrients, and temperature. Thousands of paleostudies have been made worldwide and have exemplified the power of paleolimnology in reconstructing the past at long (more than 100,000 years) and shorter (a few decades; emporal scale).

The areas where paleolimnoogy can have the most impact on human-time scales, i.e., lake restoration and management, still resist its implementation into present and future decision making, in most regions of the world. In the UK (Battarbee et al., 2005), Canada (Rühland et al., 2003), and the USA (Brenner et al., 1993), paleolimnology has been used successfully in case studies to provide the background conditions for restoration and/or to evaluate the state of lakes after restoration. However, these studies are still far from being the norm they should be. Too many restoration and management programs and management programs only refer to scarce historical data as baseline. Consequently, restoration technics applied with poorly defined scientific goals can lead to after-restoration states different from the natural state of the water body and/or failed restoration (Sondergaard et al., 2007).

In this special issue of Frontiers, researchers show how paleolimnology can be used for decision makers in restoration, and management. Saulnier-Talbot sets the scenario with her opinion on how paleodata can be better used for future management. Other papers tackle on different aspects of the use of paleolimnology for lake restoration and management. These topics are enumerated below.

(a) Quantitative methods can be used to define the baseline (or reference) conditions of a lake (i.e., conditions before a lake has been impacted by human activities). These baseline conditions can then be used to propose solutions for lake restoration and/or evaluate if restoration measures have been successful.

Fraser et al. and Whitmore et al. explain the process of developing a transfer function for quantitative TP reconstruction using diatoms, its uses and limits. Quantitative reconstruction is a powerful tool to for reference conditions but, unfortunately, not always straightforward. The two papers explain how and why.

Weckström et al. defines the reference conditions in Finnish and Chinese lakes and show how these lakes have changed in the past 150 years. Although the reference condition is not the 
same in most lakes, Finnish and Chinese lakes seem to have experienced the same directional change over the past 150 years, change created by human and climate impact.

Larocque-Tobler and Pla-Rabès exemplify how diatoms and chironomids can be used to define baseline conditions, study changes which occurred in a highly eutrophied lake in Switzerland and how this data can be used to propose restoration solutions.

Using diatoms preserved in 13 European lakes, Bennion et al. look at the impact of restoration techniques on present and past assemblages to determine if restoration was successful. They also try to determine the time needed for a lake to come back to its reference condition after restoration.

(b) Paleolimnology can be used to define how environmental changes have impacted lakes and identify the parameters to consider for management.

Gell uses multipoxy paleolimnology studies to reconstruct the history and effect of sedimentation on wetlands, and he discuss the implication of these studies on water management in Australia.

Hamilton et al. explore the effects of mining activities on Canadian lakes and evaluate the restoration techniques. They determined that pre-mining conditions were never recovered.

(c) Climate and human activities both have impacts on lakes. Understanding the impacts of both parameters is important for lake management.

\section{REFERENCES}

Battarbee, R. W., Anderson, J., Jepessen, E., and Leavitt, P. R. (2005). Combining palaeolimnological and limnological approaches in assessing lake ecosystem response to nutrient reduction. Freshw. Biol. 50, 1772-1780. doi: 10.1111/j.1365-2427.2005.01427.x

Brenner, M., Whitmore, T. J., Flannery, M. S., and Binford, M. (1993). Paleolimnological methods for defining target conditions in lake restoration: florida case studies. Lake Reserv. Manag. 7, 209-217. doi: 10.1080/07438 149309354272

Rühland, K., Priesnitz, A., and Smol, J. P. (2003). Paleolimnological evidence from diatoms for recent environmental changes in 50 lakes across canadian arctic treeline. Arct. Antarct. Alp. Res. 35, 110-123. doi: 10.1657/1523-0430(2003) 035[0110:PEFDFR]2.0.CO;2
Perga et al. proposes solutions on how to decipher the human activities and climate using a multi-proxy approach in three large lakes in France and Switzerland. Their reconstruction of human impact vs. climate can be used for future planning of these ecosystems.

(d) New techniques are being develop to extend the potential of paleolimnology for environmental reconstruction.

Perga et al. tackles the problem of species which usually do not leave hard fossils for reconstruction by using and explaining the potential of DNA.

Wiik et al. used pigments, macrofossils, cladocerans, diatoms, $\mathrm{XRF}$, and stable isotopes in a Tarn in the UK to evaluate the changes occurring during eutrophication.

\section{INCREASED OPPORTUNITIES}

Due to its great potential and robust methodologies, paleolimnology in lake management, and restoration programs, as exemplified in this special issue, will be partly conditioned by the ability of paleolimnologists to collaborate with other stakeholders.

\section{AUTHOR CONTRIBUTIONS}

The author confirms being the sole contributor of this work and approved it for publication.

Sondergaard, M., Jeppesen, E., Lauridsen, T. L., Skov, C., van Nes, E. H., Roijacjers, R., et al. (2007). Lake restoration: successes, failures and long-term effects. J. Appl. Ecol. 44, 1095-1105. doi: 10.1111/j.1365-2664.2007.01363.x

Conflict of Interest Statement: The author declares that the research was conducted in the absence of any commercial or financial relationships that could be construed as a potential conflict of interest.

Copyright (c) 2016 Larocque-Tobler. This is an open-access article distributed under the terms of the Creative Commons Attribution License (CC BY). The use, distribution or reproduction in other forums is permitted, provided the original author(s) or licensor are credited and that the original publication in this journal is cited, in accordance with accepted academic practice. No use, distribution or reproduction is permitted which does not comply with these terms. 